\title{
-Research Note- \\ Effects of suckling on the interval from calving to uterine involution in beef cows
}

\author{
Yoshiaki Izaike, Akira OKano, Kazuhiro Shimada \\ and Takao OISHI \\ Livestock Division, Chugoku National Agricultural Experimental \\ Station, Ohda-shi, Shimane 694
}

(Japan. J. Anim. Reprod., 31, 31-33, 1985)

Interval from calving to involution of uterus is a important factor determining the fertility ${ }^{1-3)}$. It has been made clear that the interval to uterus involution is affected with calving number or aging ${ }^{4,5)}$, but the influences of the other factors are almost unknown. CASIDA $^{\text {() }}$ suggested that suckling of a calf or 4 times a day milkings hastened uterine involution in dairy cows.

The present study was carried out to investigate the effect of suckling on uterine involution in beef cows.

\section{Materials and Methods}

A total number of 16 Japanese Black cows, calving numbers of which were from the 1st to the 10 th, were used. Out of 16 cows, 8 cows weaned their calves without any suckling and milking just after calving and the other 8 cows were allowed to suck with their calves ad libitum. The number of suckled and nonsuckled cows was the same at each calving number and their average calving number was 5.3.

Uterus was examined regularly by rectal palpation twice a week after 4 or 5 postpartum days and existence of lochia was observed by using of the vaginal speculum. Interval from calving to involution of uterus was judged as its end point when uterus returned to its normal and non-pregnant position, and pregnant horns showed similar values in diameter and length according to the criteria described by Higaki et al. ${ }^{7)}$. Diameter of post gravid horn was indicated by width in finger, and one width in finger was about $1.5-2.0 \mathrm{~cm}$ in this study. Degree of the diameter of uterus accompanying postpartum days which was indicated by involutionary progress curve of uterus was calculated by the fitting of orthogonal polynimials from a general recurrence formula by using NISHIDA's computer program ${ }^{3)}$, after transformation of postpartum days into natural logarithm. The involutionary progress curves in suckled and non-suckled cows were determined from 18 and 98 observations, respectively.

\section{Results and Discussion}

As shown in Table 1, average days required from calving to uterine involution was significantly $(P<0.05)$ longer in non-suckled cows than suckled ones. In suckled cows, these values were similar to those reported in other papers ${ }^{4,3,9)}$. The longer time span required for uterine involution by the increase of calv- 
Table 1. Interval from calving to involution of uterus and disappearance of lochia in suckled and non-suckled beef cows

\begin{tabular}{ccccc}
\hline \hline $\begin{array}{c}\text { Experimental } \\
\text { group }\end{array}$ & Calving No. & $\begin{array}{c}\text { No. of } \\
\text { cows }\end{array}$ & $\begin{array}{c}\text { Involution of } \\
\text { uterus (days) }\end{array}$ & $\begin{array}{c}\text { Disappearance of } \\
\text { lochia (days) }\end{array}$ \\
\hline Non-suckled & 1 & 2 & $39.5^{*}$ & $14.0^{*}$ \\
& $2-5$ & 2 & 44.5 & 15.5 \\
& $6-10$ & 4 & 48.3 & 17.7 \\
Suckled & (total) & 8 & $43.6 \pm 3.4^{\mathrm{a}}$ & $16.0 \pm 2.2$ \\
& 1 & 2 & 31.5 & 15.0 \\
& $2-5$ & 2 & 37.5 & 14.0 \\
& $6-10$ & 4 & 40.5 & 20.0 \\
& (total) & 8 & $37.5 \pm 5.8^{\mathrm{b}}$ & $17.3 \pm 4.0$ \\
\hline
\end{tabular}

* Mean a.b $P<0.05$

ing number were recognized similarly in both experimental groups. Average interval from calving to disappearance of lochia was almost the same in both experiments and was not related to the difference of calving number. It has been suggested by OXENREIDER ${ }^{10)}$ that interval to uterine involution was not influenced by suckling. However recently, OKaNo et al. ${ }^{11}$ ) reported that uterine samples of beef cows which weaned their calves just after calving and were slaughtered at 44 days postpartum showed less involutionary signs than suckled ones. These results also showed that the interval in days from calving to uterine involution was affected by suckling stimulus.

The involutionary progress curves of uterus were calculated in order to make clear the changes of the involutionary patterns of uterus for days after calving at suckled and nonsuckled treatments. In orthogonal polynomials shown by cubic equation, highly coefficient of determination ( 0.9349 at suckled, 0.9463 at non-suckled) were obtained. The values of regression coefficient in suckled cows were similar to the previous paper ${ }^{5)}$.

The involutionary progress curve of uterus accompanying the postpartum days and orthogonal polynomials are shown in Fig. 1. The average diameter of post gravid horn for

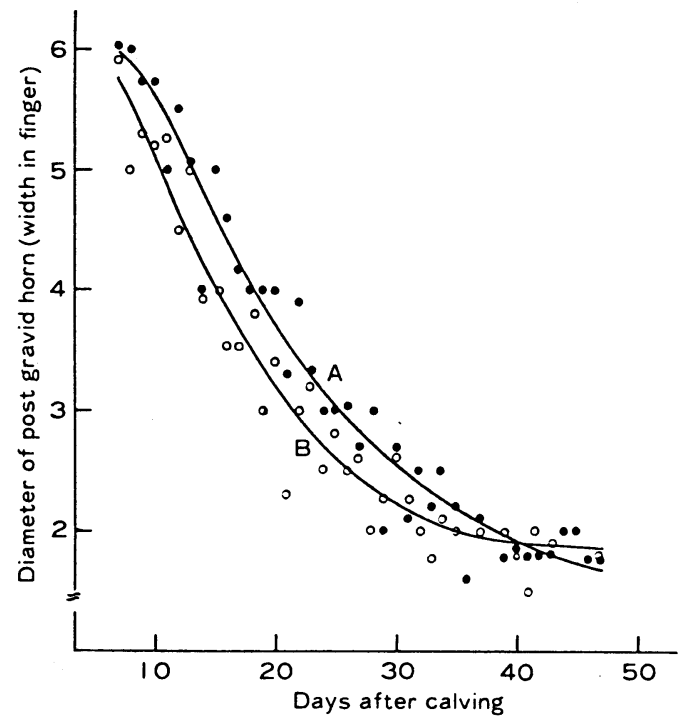

$\mathrm{A}=$ non-suckled cows

$$
\begin{aligned}
Y= & -11.0884+21.1599 \ln X-8.1472(\ln X)^{2} \\
& +0.9124(\ln X)^{3} \quad\left(r^{2}=0.9463\right) \\
\mathrm{B}= & \text { suckled cows } \\
Y= & -6.4303+17.0611 \ln X-7.2519(\ln X)^{2} \\
& +0.8777(\ln X)^{3} \quad\left(r^{2}=0.9349\right)
\end{aligned}
$$

Fig. 1. Involutionary progress curves of uterus in suckled and non-suckled beef cows. Each data point represents the mean post gravid horn diameter for all cows examined that day (• =non-suckled, $O=$ suckled).

all cows observed each postpartum days are also represented. According to the involutionary progress curves, the diameter of post gravid horn at 10,20 and 30 postpartum days in suckled cows were $5.1,3.2$ and 2.2 width 
in finger, respectively. The decrease in values from 7 to 20 postpartum days were relatively rapid compared with the later days. The involutionary pattern was almost similar to Higaki et $a l .^{7)}$, SUGA ${ }^{8)}$ and Tennant et $a l .^{12)}$ in dairly cows and previous paper ${ }^{3}$ in beef cows. In non-suckled cows, the diameter of post gravid horn at 10,20 and 30 postpartum days were $5.6,3.7$ and 2.5 width in finger, respectively. Their decreasing values were almost the same as suckled cows after 11 postpartum days and the involutionary pattern was not so remarkably changed as suckled cows. However, the decreasing values from 7 to 10 postpartum days in non-suckled cows were small compared with suckled ones, therefore, the diameter of post gravid horn in non-suckled cows was larger than the suckled cows. Consequently, it was supposed that the stimulation of suckling was not absolutely necessity for uterine involution, but, the degree of uterine involution could be accelerated with the stimulation of suckling in the early stage of postpartum days.
The author wish to thank Dr. S. Окамото the head of Livestock Division, for looking over this manuscript.

\section{References}

1) Johanns CJ, TL Clark \& JB Herrick: J.A.V. M.A., 15, 1692, 1962.

2) Shanks RD, AE Freeman \& PJ Berger: $J$. Dairy Sci., 58, 266, 1979.

3) Britt JH: J. Dairy Sci., 58, 266, 1975.

4) Marion GB, JS Norwood \& HT Gier: $A m . J$. Vet. Res., 29, 71, 1968.

5) Izaike $Y$, A Okano, K Shimada \& $T$ Oishi: Japan. J. Anim. Reprod., in press.

6) Casida LE: Wisconsin Res. Bull., 270, 48, 1968.

7) Higaki S, A Oka, Y Awai, T Kirisawa \& $\mathrm{N}$ Yoshida: Bull. National Inst. Agri. Sci., 18, $65,1959$.

8) Nishida A: Bull. Computing Center Res., 8, $135,1972$.

9) Suga T: Japan. J. Anim. Reprod., 20, xv, 1975.

10) Oxenreider SL: Am. J. Vet. Res., 29, 209, 1968.

11) Okano A, R Fukuhara, Y Shioya \& $T$ Obata: Bull. Chugoku Natl. Agric. Exp. Stn., B25, $1,1980$.

12) Tennant B, JW Kendrich \& RG Peddicord: Cornell Vet., 57, 543, 1967.

(Received May 18, 1984)

肉用牛における哺乳の有無が分婏後の子宮修復に及ぼす影響

\author{
居在家義昭・岡野 彰・島田和宏・大石孝雄
}

（農林水産省中国農業試験場鱼産部）

哺乳刺激が肉用牛の分娩後の子宮修復に及ぼす影響を 調べる目的で, 初産から 10 産の黑毛和種計 16 頭を用 いて試験した。8頭は分娩後直ちに産子を離乳し，無哺 乳区とした。他の 8 頭は産子に自由に哺乳させ, 自然哺 乳区とした。両試験区の各産次における供試頭数は同一 とし, 平均 5.3 産であった。子宮修復の状態は 3〜4 日 間隔で直腸検查により調べた。

子宮修復までの日数は無哺乳区および自然哺乳区で各
々 43. $6 \pm 3.4$ 日, $37.5 \pm 5.8$ 日 (平均士標準偏差) であ り，その差は有意であった。子宮角幅の大きさの変化を 直交多項式に当てはめて分析した結果, 子宮修復のパタ ーソに大きな違いは認められなかったが，無哺乳区では 自然哺乳区に比べ子宮角幅の減少が，とくに 10 日目頃 まで小さい傾向が認められ, 修復の程度も漣れる傾向に あることが示唆された。以上の結果, 哺乳刺激は子宮修 復に対し，促進効果があることが示唆された。 